\title{
Streptococcus agalactiae in urinary tract infections
}

\author{
F. S. Mhalu \\ M.B., Ch.B., Dip. Bact. \\ Department of Bacteriology, Royal Postgraduate Medical School, \\ Hammersmith Hospital, London W12
}

\begin{abstract}
Summary
Streptococcus agalactiae was found to be the cause of approximately $1 \%$ of urinary tract infections in a London teaching hospital in the 2 years studied. Of the forty-eight patients with this infection, fortythree were female. In nine patients the infection followed renal transplantation while in nine others it occurred in the presence of chronic renal failure. The rest, who included seven females who developed the infection following hysterectomies, had other clinical conditions which could have predisposed to such infections. The rarity of urinary tract infection by $S$. agalactiae is in contrast to the high frequency with which the organism colonizes the normal urethra. Serotypes III and II were the predominant isolates in these patients with urinary tract infections; this corresponds to the distribution of the different serotypes in the genito-urinary tract of normal individuals.
\end{abstract}

\section{Introduction}

Streptococcus agalactiae (Lancefield's group B Streptccoccus) constitutes part of the normal bacterial flora of the human lower genito-urinary tract. Carriage rates in this site vary according to methods of detection used but values up to $36 \%$ have been reported from the more recent investigations (Christensen et al., 1976; Finch, French and Phillips, 1976). Although venereal transmission of the organism has been suggested, there is no evidence to support its role as a cause of primary genital pathology (Wallin and Forsgren, 1975).

The major risk attaching to group B streptococci in the genital tract lies in their association with neonatal septicaemia and meningitis (Baker and Barrett, 1973; Yow, 1974). Little work has been done on their relationship to urinary tract infections. Eickhoff et al. (1964) reported three female patients with acute pyelonephritis from two of whom $10^{5}$ colonyforming units of the organism $/ \mathrm{ml}$ of urine were isolated. The third was diagnosed by isolation of the organism from blood culture. Wilkinson, Facklam and Wortham (1973) reported on 107 reference strains of group B streptococci from urinary tract infections but could not confirm an aetiological role for all the isolates because no quantitative bacteriological data had been provided. Other reports of group B streptococci in urinary tract infections include those by Feingold, Stagg and Kunz (1966), Anthony and Concepcion (1975) and Mhalu (1976) but to date, details of the types of patients with urinary infections with this organism have not been documented. The reported high prevalence of group B streptococci in the urethra especially in those with sexually transmitted diseases encouraged investigation into the frequency with which they cause urinary tract infections and the types of patient involved.

\section{Materials and methods}

In the period between July 1974 and June 1976, a record was kept of all significant isolations of group B streptococci from urine. The age, sex and contributory clinical condition of each patient were noted. These were compared with a $10 \%$ random sample of all patients, seen in this hospital in 1975, with urinary tract infection due to organisms other than group B streptococci. The criteria used for urinary tract infection were a pure bacterial growth of more than $10^{5}$ colony-forming units $/ \mathrm{ml}$ of freshly voided midstream urine together with pyuria. The latter was defined as more than five pus cells per high power field on microscopy of the centrifuged deposit from $10 \mathrm{ml}$ of urine resuspended in $0.5 \mathrm{ml}$. Culture was by streaking a $1 / 300 \mathrm{ml}$ loopful of well mixed urine on a MacConkey agar; a growth of 300 colonies or more represented more than $10^{5}$ organisms $/ \mathrm{ml}$. Primary sensitivity tests with ampicillin $25 \mu \mathrm{g}$; trimethoprim $1.25 \mu \mathrm{g}$; sulphafurazole $500 \mu \mathrm{g}$ and nalidixic acid $30 \mu \mathrm{g}$ or nitrofurantoin $200 \mu \mathrm{g}$ discs were done using the Stokes method (Stokes and Waterworth, 1972) whenever pus cells or organisms were evident in large numbers on microscopy. Throat and vaginal swabs were obtained from some of the patients for culture for group B streptococci. The streptococci were identified as belonging to Lancefield's group B using the antigen extraction method of Rantz and Randall (1955). Serotyping of isolates from thirty-two of the patients was done at the Streptococcus Reference Laboratory, Central Public Health Laboratory, Colindale, London. 


\section{Results}

During the 2-year period, seventy-five isolates of significant growth of $S$. agalactiae were obtained from forty-eight patients with urinary tract infections. This accounted for a $1 \%$ overall incidence of the group B Streptococcus in urinary tract infection. One patient had the organism isolated in significant numbers on eight separate occasions over a period of 4 months. Another had it isolated on four separate occasions in 1 year. It was possible to get more than one urine specimen from twenty-one of the patients before antibacterial treatment was instituted and significant isolates of group B streptococci were confirmed in all of them. All but five of the patients were adult females varying in age between 19 and 81 years. The rest were males including a prematurely born neonate whose mother's vagina was colonized by group B Streptococcus. The primary clinical conditions of the forty-eight patients subsequently proved to have urinary tract infection with $S$. agalactiae are shown in Table 1, while the clinical conditions of those with urinary tract infection due to other organisms are shown in Table 2.

All the isolates grew optimally on MacConkey agar with pale pink colonies in most cases. Occasional isolates gave obvious pink lactose fermenting colonies but these were easily distinguishable from the small magenta colonies typical of $S$. faecalis. $S$. agalactiae could further be distinguished from $S$. faecalis on the primary sensitivity plates by being fully sensitive to sulphafurazole while $S$. faecalis is invariably resistant. All the isolates were sensitive to penicillin (ampicillin) and trimethoprim but, as expected, none was sensitive to nalidixic acid. The few strains which

TABle 1. Associated clinical conditions of patients with urinary tract infections due to $S$. agalactiae

\begin{tabular}{|c|c|c|c|}
\hline \multirow[b]{2}{*}{ Clinical condition } & \multicolumn{2}{|c|}{ Sex } & \multirow[b]{2}{*}{ Total } \\
\hline & Female & Male & \\
\hline Post-renal transplant & 8 & 1 & 9 \\
\hline Chronic renal failure & 8 & 1 & 9 \\
\hline Post-hysterectomy & 7 & - & 7 \\
\hline Pregnancy & 4 & - & 4 \\
\hline Cystic kidneys & 3 & 1 & 4 \\
\hline $\begin{array}{l}\text { Normal young women (sexually } \\
\text { active age) }\end{array}$ & 3 & - & 3 \\
\hline $\begin{array}{l}\text { Disease not directly related to } \\
\text { urinary tract pathology, e.g. } \\
\text { congestive cardiac failure }\end{array}$ & 3 & - & 3 \\
\hline Ureteric obstruction & 2 & - & 2 \\
\hline $\begin{array}{l}\text { Recurrent urinary tract infection } \\
\text { Fracture of femur in elderly }\end{array}$ & 1 & - & 1 \\
\hline woman & 1 & - & 1 \\
\hline Puerperal pyrexia & 1 & - & 1 \\
\hline Diabetes mellitus & 1 & - & 1 \\
\hline Post-transurethral prostatectomy & - & 1 & 1 \\
\hline Hypertension with hemiplegia & 1 & - & 1 \\
\hline Prematurity & - & 1 & 1 \\
\hline Total & 43 & 5 & 48 \\
\hline
\end{tabular}

TABLE 2. Associated clinical conditions of a $10 \%$ random sample of patients with urinary tract infections due to organisms other than $S$. agalactiae in 1975

\begin{tabular}{|c|c|c|c|}
\hline \multirow[b]{2}{*}{ Clinical condition } & \multicolumn{2}{|c|}{ Sex } & \multirow[b]{2}{*}{ Total } \\
\hline & Female & Male & \\
\hline \multirow{2}{*}{\multicolumn{4}{|c|}{$\begin{array}{l}\text { Disease not directly related to } \\
\text { urinary tract pathology, e.g. } \\
\text { malignancies and congestive }\end{array}$}} \\
\hline & & & \\
\hline Urethral catheter in situ & 8 & 4 & 12 \\
\hline Trauma to pelvis (including & 8 & 2 & 11 \\
\hline Recurrent urinary tract infection & 10 & 1 & 11 \\
\hline $\begin{array}{l}\text { Normal young females (sexually } \\
\text { active age) }\end{array}$ & 9 & - & 9 \\
\hline Pregnancy & 7 & - & 7 \\
\hline No other condition & 6 & 1 & 7 \\
\hline $\begin{array}{l}\text { Post-hysterectomy } \\
\text { Malignancy of a pelvic organ }\end{array}$ & 6 & - & 6 \\
\hline (including urinary bladder) & 1 & 4 & 5 \\
\hline $\begin{array}{l}\text { Urine retention without } \\
\text { indwelling catheter }\end{array}$ & 2 & 3 & 5 \\
\hline Ureteric obstruction & 3 & 1 & 4 \\
\hline Diabetes mellitus & 4 & - & 4 \\
\hline Haematuria & 2 & 1 & 3 \\
\hline Urinary incontinence & 1 & 1 & 2 \\
\hline Chronic renal failure & - & 2 & 2 \\
\hline Puerperal pyrexia & 1 & - & 1 \\
\hline Post-renal transplant & 1 & - & 1 \\
\hline Cystic kidneys & 1 & - & 1 \\
\hline Total & 83 & 29 & 112 \\
\hline
\end{tabular}

TABLE 3. Serotypes of $S$. agalactiae from patients with urinary tract infections

\begin{tabular}{lc}
\hline Serotypes & $\begin{array}{c}\text { No. of } \\
\text { patients }\end{array}$ \\
\hline III & 8 \\
II & 5 \\
Ia & 4 \\
Ib & 4 \\
Ic & 2 \\
R & 2 \\
X & 2 \\
II/III & 1 \\
Non-typable & 4 \\
Total & 32 \\
\hline
\end{tabular}

were tested against nitrofurantoin proved sensitive to it. Of the five female patients who had high vaginal swabs taken in addition to urine culture, four had identical $S$. agalactiae isolates. One patient who had urinary tract infection due to the Streptococcus 1 month before labour, had identical strains of the organism isolated from her throat and vaginal swabs and from various sites on her otherwise normal newborn infant.

Serotyping results shown in Table 3 indicated that type III constituted the majority of the isolates, followed by type II. The different serotypes were widely distributed among the clinical conditions and 
within the various units where these patients were nursed so that cross infection was unlikely.

\section{Discussion}

From the results, it is evident that despite its high prevalence in the urethra, $S$. agalactiae is a rare cause of urinary tract infection. Whereas colonization rates are highest in the urethra of individuals presenting with sexually-transmitted diseases (Christensen et al., 1974; Wallin and Forsgren, 1975), urinary tract infection by the organism occurs mostly in those with structural abnormalities in the urinary tract especially if associated with immunological deficiencies. Renal transplantation and chronic renal failure were the only significant predisposing clinical conditions to urinary tract infection with $S$. agalactiae as compared to predisposing conditions to urinary tract infection with other organisms $(P<0.001$ in each case).

Some of the patients had recurrence of infection even after adequate therapy with appropriate agents including ampicillin and co-trimoxazole to which all the isolates were fully sensitive. Recurrence may have been due to inadequate eradication of the organism from the reservoir of infection which includes the vagina and possibly faeces. The predominance of serotypes III and II of the organism in urinary tract infections in this study accords with the findings of Wilkinson et al. (1973) and of Anthony and Concepcion (1975). This relative prevalence of serotypes III and II also conforms to their prevalence in the genital tract of normal individuals (Finch et al., 1976; Anthony and Concepcion, 1975). This seems to indicate that the serotypes which manage to cause disease in the urinary tract do not have any special characteristics. They simply occur according to their predominance in colonizing the normal genital tract.

\section{Acknowledgments}

This work was done while the author was on a World Health Organization fellowship grant, but the statements made and the opinions expressed are not necessarily those of the WHO.

I am grateful to Dr J. H. Darrell for advice and to Dr M. T. Parker for agreeing to have the strains serotyped.

\section{References}

ANThony, B.F. \& Concepcion, N.F. (1975) Group B Streptococcus in a general hospital. Journal of Infectious Diseases, 132, 561.

BAKer, C.J. \& BARReTt, F.F. (1973) Transmission of group B streptococci among parturient women and their neonates. Journal of Pediatrics, 83, 919.

Christensen, K.K., Christensen, P., Flamholc, L. \& RIPA, T. (1974) Frequencies of streptococci of groups A, $B, C, D$ and $G$ in urethra and cervix swab specimens from patients with suspected gonococcal infection. Acta pathologica et microbiologica scandinavica, Section B, 82, 470.

Christensen, K.K., Ripa, T., Agrup, G. \& Christensen, P. (1976) Group B streptococci in human urethral and cervical specimens. Scandinavian Journal of Infectious Diseases, 8, 75 .

Eickhoff, T.C., Klein, J.O., Daly, A.K., Ingall, D. \& FinLAND, M. (1964) Neonatal sepsis and other infections due to group B beta-hemolytic streptococci. New England Journal of Medicine, 271, 1221.

Feingold, D.S., StagG, N.I. \& Kunz, L.J. (1966) Extra respiratory steptococcal infections. Importance of the various serologic groups. New England Journal of Medicine, 275, 356.

Finch, R.G., French, G.L. \& Phillips, I. (1976) Group B streptococci in the female genital tact. British Medical Journal, 1, 1245.

MhalU, F.S. (1976) Infection with Streptococcus agalactiae in a London hospital. Journal of Clinical Pathology, 29, 309.

RANTZ, L.A. \& RANDALl, E. (1955) Use of autoclaved extracts of hemolytic streptococci for serological grouping. Stanford Medical Bulletin, 13, 290.

Stokes, E.J. \& WATERWORTH, P.M. (1972) Association of Clinical Pathologists Broadsheet No. 55 (revised).

W Allin, J. \& Forsgren, A. (1975) Group B streptococci in venereal disease clinic patients. British Journal of Venereal Diseases, 51, 401.

Wilkinson, H.W., FACKLam, R.R. \& Wortham, E.C. (1973) Distribution by serological type of group B streptococci isolated from a variety of clinical material over a fiveyear period (with special reference to neonatal sepsis and meningitis). Infection and Immunity, 8, 228.

Yow, M. (1974) Group B streptococci: a serious threat to the neonate. Journal of American Medical Association, 230, 1177. 